\title{
Front Matter: Volume 8266
}

, "Front Matter: Volume 8266," Proc. SPIE 8266, Silicon Photonics VII, 826601 (28 February 2012); doi: 10.1117/12.930628

SPIE. Event: SPIE OPTO, 2012, San Francisco, California, United States 


\section{PROCEEDINGS OF SPIE}

\section{Silicon Photonics VII}

Joel Kubby

Graham Trevor Reed

Editors

22-25 January 2012

San Francisco, California, United States

Sponsored and Published by

SPIE

Volume 8266

Proceedings of SPIE, 0277-786X, v. 8266 
The papers included in this volume were part of the technical conference cited on the cover and title page. Papers were selected and subject to review by the editors and conference program committee. Some conference presentations may not be available for publication. The papers published in these proceedings reflect the work and thoughts of the authors and are published herein as submitted. The publisher is not responsible for the validity of the information or for any outcomes resulting from reliance thereon.

Please use the following format to cite material from this book:

Author(s), "Title of Paper," in Silicon Photonics VII, edited by Joel Kubby, Graham Trevor Reed, Proceedings of SPIE Vol. 8266 (SPIE, Bellingham, WA, 2012) Article CID Number.

ISSN 0277-786X

ISBN 9780819489098

Published by

SPIE

P.O. Box 10, Bellingham, Washington 98227-0010 USA

Telephone +1 3606763290 (Pacific Time) · Fax +1 3606471445

SPIE.org

Copyright () 2012, Society of Photo-Optical Instrumentation Engineers

Copying of material in this book for internal or personal use, or for the internal or personal use of specific clients, beyond the fair use provisions granted by the U.S. Copyright Law is authorized by SPIE subject to payment of copying fees. The Transactional Reporting Service base fee for this volume is $\$ 18.00$ per article (or portion thereof), which should be paid directly to the Copyright Clearance Center (CCC), 222 Rosewood Drive, Danvers, MA 01923. Payment may also be made electronically through CCC Online at copyright.com. Other copying for republication, resale, advertising or promotion, or any form of systematic or multiple reproduction of any material in this book is prohibited except with permission in writing from the publisher. The CCC fee code is 0277-786X/12/\$18.00.

Printed in the United States of America.

Publication of record for individual papers is online in the SPIE Digital Library.

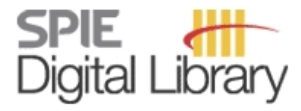

SPIEDigitalLibrary.org

Paper Numbering: Proceedings of SPIE follow an e-First publication model, with papers published first online and then in print and on CD-ROM. Papers are published as they are submitted and meet publication criteria. A unique, consistent, permanent citation identifier (CID) number is assigned to each article at the time of the first publication. Utilization of CIDs allows articles to be fully citable as soon as they are published online, and connects the same identifier to all online, print, and electronic versions of the publication. SPIE uses a six-digit CID article numbering system in which:

- The first four digits correspond to the SPIE volume number.

- The last two digits indicate publication order within the volume using a Base 36 numbering system employing both numerals and letters. These two-number sets start with 00, 01, 02, 03, 04 , $05,06,07,08,09,0 A, 0 B \ldots$. OZ, followed by 10-1Z, 20-2Z, etc.

The CID number appears on each page of the manuscript. The complete citation is used on the first page, and an abbreviated version on subsequent pages. Numbers in the index correspond to the last two digits of the six-digit CID number. 


\section{Contents}

vii Conference Committee

ix Spinoptics: Spin degeneracy removal in nanostructures (Plenary Paper) [8269-100]

V. Kleiner, N. Shitrit, E. Hasman, Technion-Israel Institute of Technology (Israel)

\section{SESSION 1 LAB-ON-A-CHIP I}

826602 Biophotonic sensors on a silicon chip for Raman spectroscopy and optical coherence tomography (Invited Paper) [8266-01]

M. Pollnau, N. Ismail, B. I. Akca, K. Wörhoff, R. M. de Ridder, Univ. of Twente (Netherlands)

826603 Temperature-independent vertically coupled double-ring sensor [8266-02]

Y. Xiong, W. N. Ye, Carleton Univ. (Canada)

826604 Investigation of parallel coupling mechanisms in silicon integrated chip sensors [8266-03]

O. Żero, A. Aksnes, Norwegian Univ. of Science and Technology (Norway)

\section{SESSION 2 LAB-ON-A-CHIP II}

826609 Photonic crystals: a versatile plafform for optics-based biological detection (Invited Paper) [8266-07]

B. T. Cunningham, Univ. of Illinois at Urbana-Champaign (United States)

\section{SESSION 3 MATERIALS}

8266 OA Photo-induced trimming of chalcogenide-assisted silicon photonic circuits (Invited Paper) [8266-08]

A. Melloni, S. Grillanda, A. Canciamilla, C. Ferrari, F. Morichetti, Politecnico di Milano (Italy); M. Strain, M. Sorel, Univ. of Glasgow (United Kingdom); V. Singh, A. Agarwal, L. C. Kimerling, Massachusetts Institute of Technology (United States)

8266 OC Glass-based silicon-clad optical device designs [8266-10]

R. C. Gauthier, K. E. Medri, Carleton Univ. (Canada)

8266 OD Loss reduction of silicon slot waveguides with ALD grown thin films [8266-11]

A. Säynätjoki, L. Karvonen, Aalto Univ. (Finland); T. Alasaarela, Beneq Oy (Finland); D. Korn, L. Alloatti, Karlsruher Institut für Technologie (Germany); A. Tervonen, Aalto Univ. (Finland);

R. Palmer, C. Koos, J. Leuthold, W. Freude, Karlsruher Institut für Technologie (Germany);

S. Honkanen, Aalto Univ. (Finland) and Univ. of Eastern Finland (Finland) 
8266 OE New concepts in silicon component design using subwavelength structures (Invited Paper) [8266-12]

I. Molina-Fernandez, R. Halir, A. Ortega-Moñux, L. Zavargo-Peche, S. Romero García,

A. Maese-Novo, D. Perez-Galacho, G. Wanguemert-Perez, Univ. de Málaga (Spain);

P. Cheben, D.-X. Xu, National Research Council Canada (Canada)

8266 OG Selecting the polarization in silicon photonic wire components (Invited Paper) [8266-14]

D.-X. Xu, A. Delâge, J. H. Schmid, R. Ma, S. Wang, J. Lapointe, M. Vachon, P. Cheben,

S. Janz, National Research Council Canada (Canada)

\section{SESSION $5 \quad$ WAVEGUIDES}

826601 Design and applications of silicon waveguide grating couplers (Invited Paper) [8266-16]

X. Chen, The Chinese Univ. of Hong Kong (Hong Kong, China) and Univ. of Surrey (United Kingdom); Z. Cheng, C. K. Y. Fung, H. K. Tsang, The Chinese Univ. of Hong Kong (Hong Kong, China)

$82660 \mathrm{~J}$ Compact and efficient couplers for silicon slot waveguides [8266-17]

A. Säynätjoki, L. Karvonen, Aalto Univ. (Finland); X. TU, T. Y. Liow, A*STAR Institute of Microelectronics (Singapore); A. Tervonen, Aalto Univ. (Finland); G. Q. Lo, A*STAR Institute of Microelectronics (Singapore); S. Honkanen, Aalto Univ. (Finland) and Univ. of Eastern Finland (Finland)

8266 OK SOI-based trapezoidal waveguide with 45-degree microreflector for non-coplanar light bending [8266-32]

P.-K. Shen, C.-C. Chang, C.-T. Chen, H.-L. Hsiao, National Central Univ. (Taiwan); Y.-C. Lee, Centera Photonics Inc. (Taiwan); M.-L. Wu, National Central Univ. (Taiwan)

$82660 \mathrm{M}$ Fabrication and characterization of parallel-coupled dual racetrack silicon microresonators [8266-19]

R. A. Integlia, L. Yin, Rutgers, The State Univ. of New Jersey (United States); D. Ding, D. Z. Pan, The Univ. of Texas at Austin (United States); D. M. Gill, Alcatel-Lucent Bell Labs. (United States); W. Song, Rutgers, The State Univ. of New Jersey (United States); Y. Qian, Rutgers, The State Univ. of New Jersey (United States) and Jilin Univ. (China); W. Jiang, Rutgers, The State Univ. of New Jersey (United States)

$82660 \mathrm{~N}$ Optical signal processing using silicon resonance and slow-light structures (Invited Paper) [8266-20]

L. Zhou, J. Chen, X. Sun, J. Xie, H. Zhu, Shanghai Jiao Tong Univ. (China)

\section{SESSION $6 \quad$ MODULATORS AND DETECTORS}

8266 OP Deep-level charge state control: a novel method for optical modulation in silicon waveguides [8266-22]

E. Huante-Ceron, D. Logan, A. P. Knights, McMaster Univ. (Canada); P. E. Jessop, Wilfrid Laurier Univ. (Canada) 
$82660 Q \quad$ A compact, high-speed, and low-cost hyperspectral imager [8266-23]

N. Tack, A. Lambrechts, P. Soussan, L. Haspeslagh, IMEC (Belgium)

\section{SESSION 7 EMITTERS AND LASERS}

8266 OR Photoluminescence and optical gain of Ga(NAsP) heterostructures pseudomorphically grown on silicon (001) substrate [8266-24]

N. Koukourakis, M. Klimasch, D. A. Funke, N. C. Gerhardt, M. R. Hofmann, Ruhr-Univ. Bochum (Germany); S. Liebich, M. Zimprich, Philipps-Univ. Marburg (Germany); B. Kunert, NAsP III/V GmbH (Germany); K. Volz, W. Stolz, Philipps-Univ. Marburg (Germany)

8266 OS Spectral characteristics of electroluminescent silicon CMOS light emitters [8266-25] A. W. Bogalecki, INSiAVA (Pty) Ltd. (South Africa); M. du Plessis, P. J. Venter, Univ. of Pretoria (South Africa); C. Janse van Rensburg, INSiAVA (Pty) Ltd (South Africa)

\section{POSTER SESSION}

8266 OY Free-carrier electro-absorption and electro-refraction modulation in group IV materials at mid-infrared wavelengths [8266-31]

M. Nedeljkovic, Univ. of Surrey (United Kingdom); R. A. Soref, Univ. of Massachusetts Boston (United States); G. Z. Mashanovich, Univ. of Surrey (United Kingdom)

Author Index 
Downloaded From: https://www.spiedigitallibrary.org/conference-proceedings-of-spie on 26 Apr 2023

Terms of Use: https://www.spiedigitallibrary.org/terms-of-use 


\title{
Conference Committee
}

\author{
Symposium Chair \\ Klaus P. Streubel, OSRAM GmbH (Germany) \\ Symposium Cochairs \\ David L. Andrews, University of East Anglia Norwich (United Kingdom) \\ Liang-Chy Chien, Kent State University (United States)
}

Program Track Chair

Yakov Sidorin, Quarles Brady LLP (United States)

\section{Conference Chairs}

Joel Kubby, University of California, Santa Cruz (United States)

Graham Trevor Reed, University of Surrey (United Kingdom)

\section{Program Committee}

Laurence W. Cahill, La Trobe University (Australia)

Philippe M. Fauchet, University of Rochester (United States)

L. Cary Gunn, Genalyte, Inc. (United States)

Siegfried Janz, National Research Council Canada (Canada)

Andrew P. Knights, McMaster University (Canada)

Laura Maria Lechuga, Centro d'Investigacions en Nanociència i Nanotecnologia (Spain)

Sebania Libertino, Istituto per la Microelettronica e Microsistemi (Italy)

Goran Z. Mashanovich, University of Surrey (United Kingdom)

Mario J. Paniccia, Intel Corporation (United States)

Andrew W. Poon, Hong Kong University of Science and Technology (Hong Kong, China)

Holger Schmidt, University of California, Santa Cruz (United States)

Dan-Xia Xu, National Research Council Canada (Canada)

Zhiping Zhou, Peking University (China)

Session Chairs

1 Lab-on-a-Chip I

Holger Schmidt, University of California, Santa Cruz (United States)

2 Lab-on-a-Chip II

Holger Schmidt, University of California, Santa Cruz (United States) 
3 Materials

Graham Trevor Reed, University of Surrey (United Kingdom)

4 Photonic Crystals and Wires

Graham Trevor Reed, University of Surrey (United Kingdom)

$5 \quad$ Waveguides

Graham Trevor Reed, University of Surrey (United Kingdom)

6 Modulators and Detectors

Jung Hun H. Shin, KAIST (Korea, Republic of)

$7 \quad$ Emitters and Lasers

Philippe M. Fauchet, University of Rochester (United States) 